\title{
Translation: "Un átomo a otro"
}

\author{
Jessica Aliaga Lavrijsen \\ University of Zaragoza \\ jeskeal@hotmail.com
}

Brian McCabe (b. 1951) is a renowned Scottish writer. He has published five poetry collections: Goodbye Schooltie (1972), Spring 's Witch (1984), One Atom to Another (1987), Body Parts (1999) and Zero (2009); several collected stories: The Lipstick Circus (1985), In a Dark Room with a Stranger (1995), A Date with my Wife (2001) and Selected Stories (2003); and a novel: The Other McCoy (1990). He has also published several articles of literary criticism and, currently, he is the editor of the literary journal "The Edinburgh Review".

His work has been acclaimed and he has received six awards from The Scottish Arts Council, two poetry awards and The Canongate Prize. Some of his tales have been read on $B B C$ Radio 3, $B B C$ Radio Scotland, and BBC Radio 4; others have been adapted for television, theatre and even film.

His impact on the literary activity of Edinburgh is intense, since he has been teaching creative writing at British universities for several years and he frequently participates in public readings and other literary events.

"Un átomo a otro".

No puedo creerlo.

¿Cuántos milenios hace?

No me digas que no me reconoces

Pero si estuvimos juntos en la misma molécula

一en la sopa.
"One Atom to Another"

I don't believe it.

How many millennia is it?

Don't tell me you don't recognise me?

But we were in the same molecule together -in the soup. 
Átomo, no has envejecido ni un día. ¿Te acuerdas de aquella vez en la que nos emborrachamos juntos

de aminoácidos? Y después formamos nuestra primera proteína -Madre mía, en aquellos tiempos sí que vivíamos peligrosamente.

Sí, tuvimos nuestros roces.

Al final rompimos lazos.

Después oí que te habías trasladado -

que trabajabas para alguna compañía nueva

llamada A.D.N.

Yo me quedé en mi elemento.

No viajo mucho, pero soy feliz.

Casi me echan el lazo pero

se deshizo - uno de los Carbonos.

¿Te acuerdas de los Carbonos?

Siempre supe que serías alguien.

Estuve detrás de ti todo el tiempo

desde que te arrastraste de ese mar

hasta que te convertiste en lo que eres hoy.

¿Qué tal van las cosas por la industria de la

vida?

Oí lo de tu colapso.

Hiroshima. Nagasaki.

Te presionaron vale vale

no tienes por qué darme explicaciones.

Me encantaría oír tus planes, pero

tienes que salir disparado ya. Bien.

Ha sido genial toparme contigo de nuevo.

No suelo tropezarme con celebridades.

Deberíamos juntarnos más a menudo.

No en serio.

¡Tanto tiempo!
Atom you don't look a day older.

Remember that time we got drunk together on amino acids? And then we

Formed the first protein $-\mathrm{O}$ mother, in those days we lived dangerously.

O I know we got on each other's particles. We fell out eventually.

Later I heard you'd moved -

working for some new company

called D.N.A.

Me, I stayed in my element.

Don't get around much, but I'm happy.

Almost got hitched, but it

fell apart - to one of the Carbons.

Remember the Carbons?

I always knew you'd be somebody.

I was right behind you all the way

when you crawled up out of the sea

and evolved in what you are today.

How is it in the life industry?

Heard about your breakdown.

Hiroshima. Nagasaki.

You were put under pressure okay okay you don't have to explain yourself to me.

I'd love to hear your plans, but then you've got to shoot off now. So.

Great to bump into you again.

Not often I collide with a celebrity.

We should get together more often.

No seriously.

So long.

McCabe, Brian. 1987. One Atom to Another. Edinburgh: Polygon, p. 75-76 